\title{
Fertility preservation in women-a practical guide to preservation techniques and therapeutic strategies in breast cancer, Hodgkin's lymphoma and borderline ovarian tumours by the fertility preservation network FertiPROTEKT
}

\author{
Michael von Wolff • Markus Montag • \\ Ralf Dittrich • Dominik Denschlag • \\ Frank Nawroth • Barbara Lawrenz
}

Received: 8 November 2010/ Accepted: 2 March 2011/Published online: 24 March 2011

(c) The Author(s) 2011. This article is published with open access at Springerlink.com

\begin{abstract}
Purpose Fertility preservation methods are playing an increasing role in women up to the age of 40 years because of rising survival rates in those affected by cancer. However, balanced practical recommendations concerning all relevant fertility preservation, to support doctors in counselling and treating patients, are still rare.

Methods These recommendations were prepared by the network FertiPROTEKT (http://www.fertiprotect.eu), a collaboration of around 70 centres in Germany, Switzerland and Austria. The recommendations were developed by specialists in reproductive medicine, reproductive biology and oncology, which gave a comprehensive overview of all named techniques as well as their benefits and risks. Furthermore, practice-orientated recommendations for the
\end{abstract}

In the name of all members of the network FertiPROTEKT.

M. von Wolff $(\bowtie)$

Department of Gynaecological Endocrinology and Reproductive

Medicine, University Women's Hospital, Effingerstrasse 102,

3010 Bern, Switzerland

e-mail: Michael.vonWolff@insel.ch

M. Montag

Department of Gynaecological Endocrinology and Reproductive

Medicine, University Women's Hospital, Bonn, Germany

R. Dittrich

University Women's Hospital, Erlangen, Germany

D. Denschlag

Hochtaunus-Kliniken, Bad Homburg, Germany

F. Nawroth

Hormon- und Pränatalzentrum, Hamburg, Germany

B. Lawrenz

University Women's Hospital, Tuebingen, Germany individual use of fertility preservation methods for various indications such as breast cancer, Hodgkin's lymphoma and borderline ovarian tumours are given.

Results Various options such as ovarian stimulation and cryopreservation of unfertilised or fertilised oocytes, cryopreservation and transplantation of ovarian tissue, GnRH-agonist administration and transposition of the ovaries can be offered. All the techniques can be performed alone or in combination within a maximum of 2 weeks with low risk and different success rates.

Conclusions Fertility preservation in women has become an option with realistic chances to become pregnant after cytotoxic therapies. The information provided allows a well balanced and realistic counselling and treatment.

Keywords Cancer - Fertility preservation - Oocytes . Ovarian tissue $\cdot$ Cryopreservation $\cdot$ GnRH agonists

\section{Introduction}

Increasing survival rates in patients affected by oncological disease and advances in reproductive medicine have led to the development and increasing use of various fertility preservation techniques. Over the last few years, several techniques have been particularly favoured despite insufficient data and others have not been recommended. Meanwhile however, improving data and optimisation of the available techniques have allowed a realistic portrayal of the efficacy and risks of the most commonly used methods as well as recommendations for the use of the techniques alone or in combination. Many recommendations can be found in the literature on fertility protection; however, there is no current publication which objectively considers all the established techniques [1, 2]. Furthermore, 
most work focuses only on the techniques as such or on their relevance in various disease states without considering both aspects and connecting them with one another. Recommendations from the FertiPROTEKT Network [3], described below, were formulated for clinical practice in such a way that not only the techniques are objectively represented, but also recommendations for their use in clinical practice for the commonest oncological diseases are also given. The recommendations, developed by specialists in reproductive medicine and reproductive biologists as well as oncologists, avoid a detailed listing of all the underlying work, and rather summarise their key messages and reinforce them with information from current publications or review articles. This concept allows a comprehensive and practice-orientated description of a complex topic and an application for specialists in reproductive medicine and oncologists.

The general recommendations for the counselling on and use of fertility preservation methods are presented first in the following review (Fig. 1), followed by the techniques, a description of their efficacy and risks, and finally a discussion of their use in breast cancer, Hodgkin's lymphoma and borderline ovarian tumours (Tables 1, 2, 3 and 4).

\section{General recommendations}

- All women between the ages of ca. 14 and 40 years who receive chemotherapy which could lead to a significant chance of disruption to their ovarian function should be counselled by a doctor trained in reproductive medicine on fertility preservation methods, in agreement with the responsible oncologists.

- All applicable methods should be included in the counselling.

- All counselling and treatments, including complications which occur, should be documented in the records.

- Performing fertility preservation techniques, i.e. due to the postponement of a cytotoxic therapy, must not affect the efficacy of the oncological regimen.
Fig. 1 Simplified regimen for the use of fertility preservation procedures. It should be noted that the choice of method also depends on the patient's age, their prognosis, the toxicity of the chemotherapy and the individual wishes of the patient and their partner

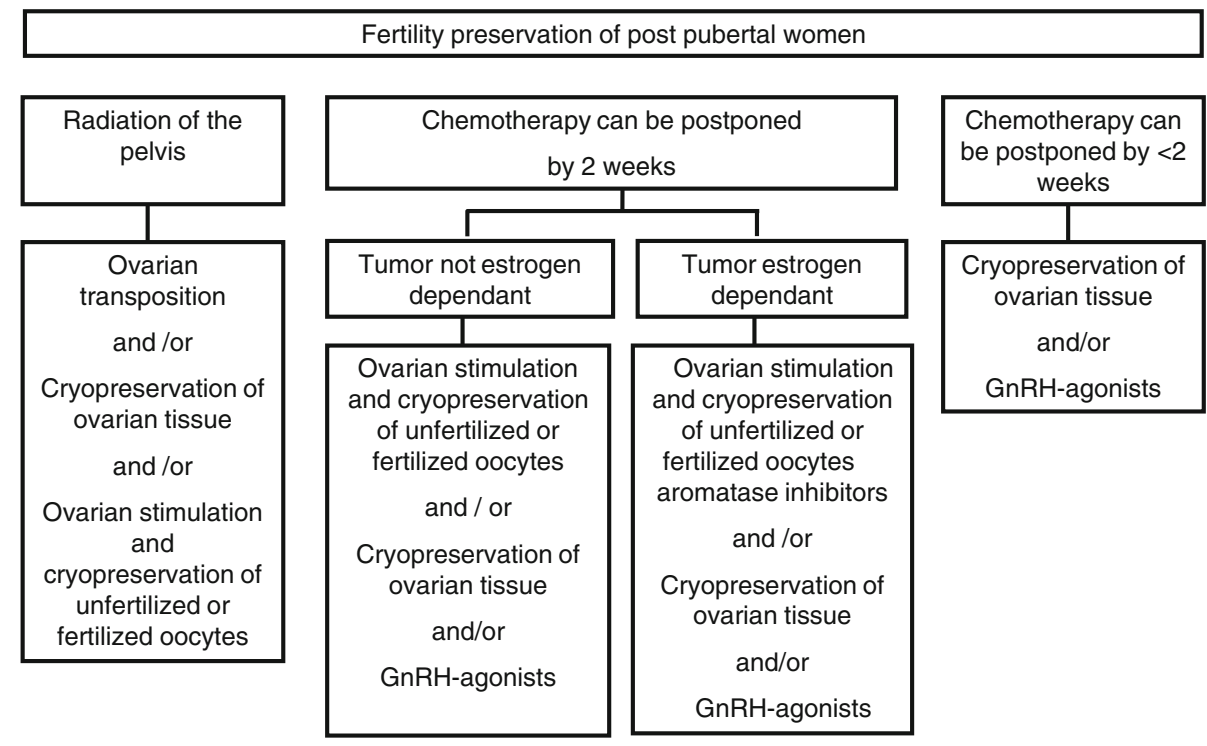

Table 1 Breast cancer: chemotherapy-associated amenorrhoea rate $(\mathrm{A}=$ doxorubicin; $\mathrm{C}=$ cyclophosphamide; $\mathrm{E}=$ epirubicin; $\mathrm{F}=5$-fluorouraci; $\mathrm{M}=$ methotrexate (modified according to [39])

\begin{tabular}{llr}
\hline Age (years) & Chemotherapy & Rate of amenorrhoea (\%) \\
\hline$>40$ & $6 \times \mathrm{CMF}, 6 \times \mathrm{FEC}, 6 \times \mathrm{FAC}$ & $>80$ (High risk) \\
$<40$ & High-dose EC & \\
$30-39$ & $6 \times \mathrm{CMF}, 6 \times \mathrm{FEC}, 6 \times \mathrm{FAC}$ & $20-80$ (Moderate risk) \\
$>40$ & $4 \times \mathrm{AC}$ & \\
$<30$ & $6 \times \mathrm{CMF}, 6 \times \mathrm{FEC}, 6 \times \mathrm{FAC}$ & $<20$ (Low risk) \\
$<40$ & $4 \times \mathrm{AC}$ & \\
\hline
\end{tabular}

Insufficient data: taxanes, monoclonal antibodies, avastin ${ }^{\circledR}$ (bevacizumab), lapatinib, herceptin ${ }^{\circledR}$ (trastuzumab) and gemzar ${ }^{\circledR}$ (gemcitabine) 
Table 2 Breast cancer: fertility preservation procedures depending on hormone receptor status and oncological treatment plan in women with a medium to high risk of amenorrhoea

\begin{tabular}{|c|c|c|c|c|}
\hline & \multicolumn{2}{|c|}{$\begin{array}{l}\text { Adjuvant situation (fertility preservation after } \\
\text { surgery and before chemotherapy) }\end{array}$} & \multicolumn{2}{|c|}{$\begin{array}{l}\text { Neoadjuvant situation (fertility preservation } \\
\text { before chemotherapy and before surgery) }\end{array}$} \\
\hline & $\begin{array}{l}\text { Hormone } \\
\text { receptor } \\
\text { negative }\end{array}$ & $\begin{array}{l}\text { Hormone } \\
\text { receptor } \\
\text { positive }\end{array}$ & $\begin{array}{l}\text { Hormone } \\
\text { receptor } \\
\text { negative }\end{array}$ & $\begin{array}{l}\text { Hormone } \\
\text { receptor } \\
\text { positive }\end{array}$ \\
\hline $\begin{array}{l}\text { Hormonal stimulation and } \\
\text { cryopreservation } \\
\text { of unfertilised and fertilised oocytes }\end{array}$ & + & $\begin{array}{l}(+) \\
( \pm \text { combination with } \\
\text { letrozole })\end{array}$ & $\begin{array}{l}(+) \\
( \pm \text { combination with } \\
\text { letrozole })\end{array}$ & - \\
\hline Cryopreservation of ovarian tissue & + & + & + & + \\
\hline $\begin{array}{l}\text { Combination of hormonal stimulation } \\
\text { and cryopreservation of oocytes } \\
\text { and ovarian tissue }\end{array}$ & + & $\begin{array}{l}(+) \\
( \pm \text { combination with } \\
\text { letrozole })\end{array}$ & $\begin{array}{l}(+) \\
( \pm \text { combination with } \\
\text { letrozole })\end{array}$ & - \\
\hline GnRH-agonists & + & $(-)$ & + & $(-)$ \\
\hline
\end{tabular}

Table 3 Hodgkin's lymphoma-Chemotherapy-associated amenorrhoea rate $(\mathrm{A}=$ adriamycin; $\mathrm{B}=$ bleomycin; $\mathrm{C}=$ cyclophosphamide; $\mathrm{E}=$ etoposide; $\mathrm{O}=$ oncovin; $\mathrm{P}=$ procarbazine and prednisone $\mathrm{V}=$ vinblastine) modified according to [40])

\begin{tabular}{lll}
\hline Age (years) & Chemotherapy & $\begin{array}{l}\text { Rate of } \\
\text { amenorrhoea } \\
(\%)\end{array}$ \\
\hline$\geq 30$ & $2 \times$ ABVD (HD 7, arm B) & 0 \\
$<30$ & $2 \times$ COPP/ABVD (HD 8) & 5.6 \\
$\geq 30$ & & 12.2 \\
$<30$ & $4 \times$ COPP/ABVD (HD 9 A) & 3.5 \\
$\geq 30$ & & 53.3 \\
$<30$ & $8 \times$ BEACOPP (HD 9, arm B) & 23.5 \\
$\geq 30$ & & 42.1 \\
$<30$ & 8 BEACOPP escalated (HD 9, Arm C) & 70.4 \\
$\geq 30$ & & 40.4 \\
$<30$ & & \\
\hline
\end{tabular}

\section{Fertility protection techniques}

Ovarian stimulation and cryopreservation

of unfertilised and fertilised oocytes

\section{Indications and requirements}

- Postmenarchal women up to the age of 40 years with a sufficient ovarian reserve, who receive chemotherapy or another treatment which could lead to a significant chance of premature ovarian insufficiency or loss of ovarian function

- The time until the start of chemotherapy is at least 2 weeks

\section{Description of ovarian stimulation}

- Starting stimulation during menstruation: perform a classic GnRH-antagonist protocol, as this is associated with a lower risk of ovarian hyperstimulation syndrome (OHSS) [4]

- Starting stimulation in other cycle phases: GnRHantagonist immediately and simultaneously start administering recombinant follicle stimulating hormone (FSH) [5]

- Induction of ovulation in the case of impending OHSS with triptorelin $0.2 \mathrm{mg}$ [6]

- In the case of estrogen-dependent tumours, stimulation can be combined with letrozole $5 \mathrm{mg}$ daily [7], which is administered at the same time as the gonadotrophin.

\section{Description of cryopreservation of fertilised and unfertilised oocytes}

To reduce the risk of fertilisation failure, intracytoplasmic sperm injection (ICSI) should be considered, with only justifiable exceptions, and independent of the spermiogram.

Unfertilised oocytes are preserved by slow freezing or vitrification. According to the current data, vitrification appears to be more effective $[8,9]$. Cryopreservation of unfertilised oocytes by vitrification should only be performed when internal controls have shown that there is technique proficiency.

\section{Success rates}

On average, 11.6 oocytes from 205 follicle punctures were collected in the FertiPROTEKT Network (STD: $\pm 7.7 ; 25 \%$ quartile: $n=6 ; 75 \%$ quartile: $n=15$ ). The fertilisation 
Table 4 Hodgkin's lymphoma: Fertility preservation procedures for the chemotherapy regimens currently performed by the German Hodgkin's Society [36]

\begin{tabular}{|c|c|c|c|}
\hline & ABVD & BEACOPP & BEACOPP escalated \\
\hline $\begin{array}{l}\text { Hormonal stimulation and cryopreservation of unfertilised } \\
\text { and fertilised oocytes }\end{array}$ & - & + & + \\
\hline Cryopreservation of ovarian tissue & - & + & + \\
\hline $\begin{array}{l}\text { Combination of hormonal stimulation and cryopreservation } \\
\text { of oocytes and ovarian tissue }\end{array}$ & - & + & + \\
\hline GnRH-agonists & $(+)$ & + & + \\
\hline
\end{tabular}

rate was $61.3 \%$. If fertilisation was carried out on all oocytes, the following number of fertilised oocytes resulted in each age group: 18-25 years; 8.5 oocytes, $26-30$ years; 7.3 oocytes, $31-35$ years; 6.1 oocytes, $36-40$ years; 5.1 oocytes $[10,11]$.

After cryopreservation of unfertilised oocytes, each thawed, surviving egg cell had an implantation potential of $6-8 \%$. This applies to vitrification as well as to the new and adapted slow egg freezing protocols [9].

Risks

Significant risks are ovarian hyperstimulation syndrome (OHSS) or the collection of immature oocytes with a low fertilisation potential. According to the complication records from FertiPROTEKT from 205 follicle punctures performed, no oocytes could be preserved in three cases. Significant overstimulation did not occur [11].

Cryopreservation of ovarian tissue

\section{Indications and requirements}

- Girls and women up to the age of ca. 35-37 years and with an age-appropriate ovarian reserve who receive chemotherapy or another treatment which could lead to a significant chance of premature ovarian insufficiency

- With oncological disease: exclusion of ovarian metastases using appropriate diagnostic imaging

- Exclusion of an oncological disease which is associated with a high risk of ovarian metastases (haematological neoplasias, metastatic breast cancer, ovarian cancer, etc.)

- The time until the start of chemotherapy is at least 3 days

- Low risk intubation of the patient and surgery is possible (caution: mediastinal tumours in patients with Hodgkin's lymphoma)

\section{Description}

Removal of ovarian tissue: removal of the ovarian tissue is performed laparoscopically where possible. The amount of tissue removed depends on the expected probability of losing all egg cells. Histological examination of a reference biopsy (to exclude tumour cells, proof of follicle presence) is necessary.

Transport from operating theatre to laboratory: rapid transport of the removed tissue is performed in transport medium on ice. However, transport from the place of removal to the tissue bank is also possible over a longer period of time $(<20 \mathrm{~h})[12,13]$.

Cryopreservation: the most efficient method of cryopreservation is currently the slow freezing technique [14]. Testing the effectiveness of the freezing method is recommended, for example by transplanting thawed tissue into immunodeficient mice.

Retransplantation: orthotopical transplantation hasaccording to the current literature-the greatest chance of success [15]. It is still unclear which exact site should be used for the transplant, whether a spontaneous pregnancy or IVF should be given priority and how the patient should be treated after the transplant. The transplantation should in most cases be performed 2 years after the end of treatment at the earliest, in agreement with the responsible oncologists, when the risk of relapse has significantly decreased.

\section{Success rates}

Fourteen births have been reported up to now. Spontaneous pregnancies occurred as well as pregnancies after IVF treatment. Successful teams [16] have achieved a pregnancy rate of ca. $30 \%$ per transplantation up to now, although the birth rate is lower. However, other teams report lower success rates, so it can be assumed that the success depends on the correct indication for cryopreservation, the age of the patient, the freezing technique and the transplantation technique.

A maximum age limit of ca. 35-37 years is recommended for the cryopreservation of ovarian tissue [15].

\section{Risks}

One surgical revision after laparoscopic tissue removal from of a total of 500 laparoscopies has been documented 
in the FertiPROTEKT Network records [11]. A further risk is the retransplantation of tumour tissue. Up to now, metastases have been described in a cryoconserved specimen from a patient with Hodgkin's lymphoma [17], however not with breast cancer [18].

The risk of a remetastasis after retransplantation is unforeseeable in patients with haematological neoplasias or a high risk of ovarian metastasis [19], therefore this should not be performed at the present time.

\section{GnRH-Agonists (GnRHa)}

\section{Indication}

- Postmenarchal women up to the age of 40 years, who receive chemotherapy or another treatment which could lead to a significant chance of premature ovarian insufficiency.

As a definitive proof of efficacy is not yet available, other techniques should also be considered in addition to drug treatment.

\section{Description-GnRHa}

After an initial gonadotrophin release (flare-up effect), GnRHa bring about a downregulation of the GnRH receptor, followed by hypogonadism. Further possible protective mechanisms on the gonads are under discussion [20].

The flare-up effect of the GnRHa takes about 1 week; they should therefore be administered at least 1 week before the start of chemotherapy. If the flare-up needs to be reduced, a GnRH-antagonist can be administered once a day for 6 days at the same time as the GnRHa depot injection [21]. Whether the fertility preserving effect of GnRHa can thereby be improved has yet to be proven.

The effect of the GnRHa should continue for at least 1-2 weeks after the last chemotherapy cycle.

\section{Success rates of GnRHa}

Twelve studies carried out between 1966 and 2008 showed that out of 234 patients who received chemotherapy, 59\% of cases had premature ovarian failure (POF) versus $9 \%$ after a combination of chemotherapy with a GnRHa $(n=345)$ [22]. A summary of nine studies (1980-2008) confirmed these results with a POF rate of 55.5 versus $11.1 \%(n=189$ vs. $n=225)$ [20].

In 2009 and 2010, three meta-analyses were published addressing the co-treatment GnRHa during chemotherapy to reduce ovarian damage (23-25). Clowse et al. [23] and BenAharon et al. [24] included 8, 16 studies, respectively, including those with retrospective controls. Clowse revealed that $\mathrm{GnRHa}$ are effective in preserving ovarian function (RR 1.68) and Ben-Aharon revealed that GnRHa are effective in reducing amenorrhoea (RR 0.26). Bedaiwy et al. [25] only included prospective randomized studies $(n=7)$ with 173 patients receiving GnRHa and 167 control patients. They calculated an odds ratio of 3.5 favouring the use of GnRHa.

On the whole, the evidence that GnRHa have a protective effect on the ovaries is becoming more established. Nevertheless, the final conformation is still awaited.

Risks

One possible side effect of GnRH analogues is menopausal symptoms. These symptoms are delayed, but are also possible with chemotherapy alone. Treatment with GnRHa for over 6 months leads to a loss of bone mass [26]. In case of severe symptoms and in case of long term use ( $>6$ month), add-back therapies, using low estrogen dosages, can be considered. However, data concerning the influence of add-back therapies on the fertility preserving action of GnRHa are not available.

There is a theoretical risk of reducing the efficacy of chemotherapy when using GnRHa in a patient with estrogen receptor positive breast cancer, but there is no conclusive evidence for or against this hypothesis. As the data is unclear, GnRHa should not be used where estrogen receptor positive disease is present, or should only be used after a careful risk/benefit analysis.

\section{Combination of the techniques}

Fertility preservation procedures can be combined to increase their efficacy (Fig. 2).

Ovarian tissue can be removed laparoscopically and ovarian stimulation can be started ca. 1-2 days later [27]. The theoretical chance of pregnancy is almost doubled with this combination. Use of the luteal phase stimulation protocol is recommended if the stimulation is stared after the fifth day of the cycle [5]. Additional administration of an aromatase inhibitor should be considered if breast cancer is present [7]. Short acting GnRHa are used for ovulation induction [6], which can be combined with a GnRHa depot. Chemotherapy can be started 1-2 days after follicle aspiration.

Starting chemotherapy before recovery of the ovaries after stimulation did not lead to more damage to the ovaries in an animal study [28].

Transposition of the ovaries

\section{Indications}

- Radiotherapy to the pelvis, which would lead to a significant chance of premature ovarian insufficiency. 


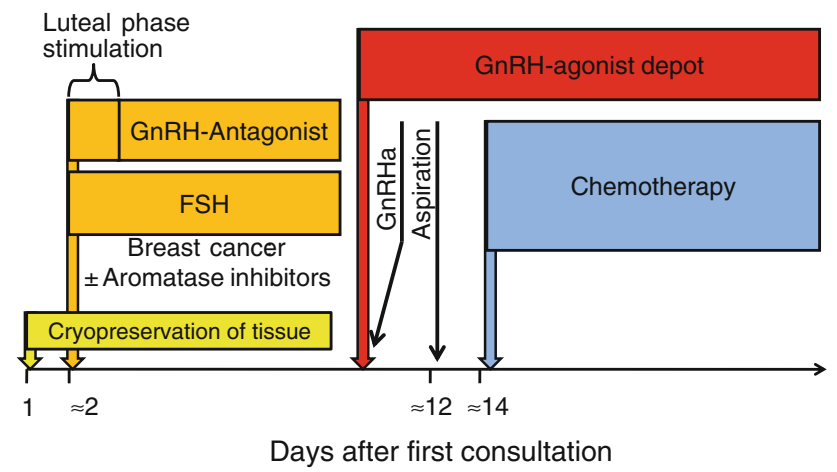

Fig. 2 Combination of the various fertility preservation methods to increase the chance of pregnancy

Radiotherapy with two Gray leads to a loss of ca. $50 \%$ of the primordial follicles [29]. The chance of premature ovarian insufficiency occurring in women aged $\geq 20$ years is almost $100 \%$ if they receive radiotherapy with 15 Gray [30].

\section{Description}

The mobilised ovary is usually transposed craniolaterally, fixed and marked with clips in order to achieve the greatest distance possible from the main irradiated area [31, 32]. As loss of ovarian function can occur despite transposition, additional cryopreservation of the ovarian tissue is recommended.

\section{Success rates}

According to the published literature, there is a success rate of up to $85 \%$ with this technique in patients with regular ovulatory cycles, and also in patients under the age of 40 after radiotherapy [31].

Risks

Unspecific post-operative abdominal discomfort has been described, which was a result of ovarian cysts or peritoneal adhesions in most cases. From a group of 51 patients, surgical revision was necessary in 9 of them to relieve pain [33].

\section{Fertility preservation techniques and common malignancies}

Breast cancer

\section{Risk of treatment-induced amenorrhoea}

The risk of chemotherapy-induced amenorrhoea can only be roughly estimated because of the limited data available.
Table 1 summarises the available studies and allows an approximate, age-dependent estimation of the risk. There is insufficient data for a risk calculation for taxanes, monoclonal antibodies, Avastin ${ }^{\circledR}$ (bevacizumab), lapatinib, Herceptin ${ }^{\circledR}$ (trastuzumab) and Gemzar ${ }^{\circledR}$ (gemcitabine).

\section{Fertility protection options}

The fertility protection options are shown in Table 2 .

In the adjuvant situation, i.e. after tumour removal, the time from diagnosis to the start of chemotherapy is usually $\geq 2$ weeks, therefore all available methods of fertility preservation can be offered in theory. In the neoadjuvant situation, ovarian stimulation should rather not be performed, as the tumour is still present during stimulation.

There are insufficient data about the risk associated with hormonal stimulation and receptor positive breast cancer. There is a theoretical risk of tumour progression with increased estrogen levels. However, one argument against this is that patients who do not undergo fertility preservation treatments maintain their menstrual cycles until chemotherapy, and therefore continue to have an endogenous estrogen synthesis. Furthermore, a study of 91 patients who became pregnant after recovering from breast cancer showed no increased risk of relapse [34].

As the risk of relapse is still unclear, ovarian stimulation in a patient with receptor positive breast cancer must be discussed in detail with the patient after a careful riskbenefit analysis with the responsible oncologists.

Alternatively, the stimulation treatment can be combined with aromatase inhibitors [7]. The estrogen levels increase much less with this treatment. An increased risk of breast cancer relapse has not been found up to now in 79 patients who underwent this treatment [35]. If there are no concerns about giving ovarian stimulation, it can be combined with cryopreservation of ovarian tissue [27].

Treatment with a GnRHa should be possible without risk in receptor-negative breast cancer patients. If receptorpositive breast cancer is present, it cannot be ruled out that the low estradiol values present under GnRHa treatment could lead to a reduced tumour cell sensitivity to the chemotherapy. However, data concerning this theory is still lacking. As a result of this, GnRHa treatment in a patient with receptor-positive breast cancer must be discussed in detail with the patient after a careful risk-benefit analysis with the responsible oncologists.

Hodgkin's lymphoma

\section{Risk of treatment-induced amenorrhoea}

The risk of chemotherapy-induced amenorrhoea can only be roughly estimated because of the limited data available. 
Table 3 allows an approximate, age-dependent estimation of the risk.

\section{Fertility protection options}

Possible fertility preservation methods are shown in Table 4. Only treatments which are currently carried out by the German Hodgkin's Study Group [36] are listed.

The risk of damage to the gonads with treatment according to the ABVD-regimen is low, and in such a case, fertility preservation techniques are not usually necessary.

If the patient is undergoing treatment according to the BEACOPP or BEACOPP-escalated regimen, an individual and age-related risk-benefit analysis should be carried out with the oncologists and the patient, and fertility preservation treatment should be started if necessary.

If ovarian tissue is to be cryoconserved and the patient has a mediastinal tumour, the increased anaesthesia risk should be taken into consideration. All forms of fertility preservation methods are otherwise possible, alone or in combination, in a time frame of $\geq 2$ weeks.

\section{Borderline ovarian tumours}

\section{Oncological treatment}

The standard treatment of this disease is surgical removal of the tumour including surgical staging. In the case of unilateral disease and a desire to conceive, a macroscopically unsuspicious contralateral ovary with tube and uterus can be preserved.

An ovary-damaging biopsy of the unsuspicious contralateral ovary which has shown negative histology still cannot reliably exclude that the ovary is actually affected, therefore this surgical procedure is not recommended. In the case of bilateral tumours, ovary-preserving extirpation is justifiable, after discussing the increased risk of relapse with the patient.

\section{Fertility protection options}

According to a review of the studies published up to now, the risk of relapse of a borderline tumour after ovarian stimulation treatment was $19.4 \%(n=12 / 62)$ [37]. However, none of these relapses resulted in death. Nevertheless, the patient should be informed that stimulation treatment maybe associated with an increased risk of relapse.

Cryopreservation of ovarian tissue is recommended by several teams in the international literature [38]. If the tissue is to be retransplanted at a later date, however retransplantation of borderline tissue or the de novo development of a borderline tumour cannot be excluded. The patients must be informed about this risk accordingly and only tissue with a high probability of not containing any borderline tissue should be cryoconserved.

In principle, a pregnancy spontaneously occurring after fertility preservation surgery or ovarian stimulation is preferable to cryopreservation of ovarian tissue so that the ovarian reserve is not further reduced by the removal of ovarian tissue.

\section{The network FertiPROTEKT}

FertiPROTEKT (www.fertiprotekt.eu) was introduced in 2006 and is a network of around 70 university based, hospital based and private infertility and oncology centres. Its main goal is the nationwide introduction of local fertility preservation programmes in Germany, Switzerland and Austria, involving such techniques which give the patients the highest chance to achieve a pregnancy. The techniques-performed separately or in combination-are those which can be performed by most of the infertility centres and associated hospitals such as transposition of the ovaries, ovarian stimulation, cryopreservation of oocytes, zygotes and embryos as well as cryopreservation of ovarian tissue and application of GnRH-agonists. Purely experimental techniques such as xenotransplantation of ovarian tissue and techniques which are apparently only successful in specialized centres such as In vitro Maturation are therefore not considered. Techniques, requiring highly sophisticated expertise such as cryopreservation of ovarian tissue are performed by only a few centres which fulfill certain quality criteria.

A further goal of the network is to train all involved centres in fertility preservation techniques and to perform quality control procedures.

All network members need to attend the annual conference of the network and must provide data for a register about their fertility preservation treatments, and the resulting pregnancies. These data and the number of treatments per centre are published on the website of the network to allow patients to choose those centres with the highest experience.

The network also provides information about treatments, its centres, etc. on bilingual (German and English) website (http://www.fertiprotekt.eu). Around 7,000 website hits are registered every month.

The recommendations described in this article have been prepared by different specialists including infertility specialists and oncologists. They had been circulated among all member of the network and have been discussed in detail at the annual conferences among the around 100 participants in detail. The recommendations were adapted according to the suggestions and were finalised by a board of infertility specialists and oncologists. 
Acknowledgments We would like to thank the following specialists in reproductive medicine and oncologists who also contributed to the recommendations described in this paper: Behringer, Karolin; Cologne, Germany; Dorn, Christoph; Hamburg, Germany; Hirchenhain, Jens; Düsseldorf, Germany; Hoppe, Ines; Jena, Germany; Jantke, Andreas; Berlin, Germany; Kissler, Stefan; Duesseldorf, Germany; Korell, Matthias; Duisburg, Germany; Montag, Markus; Bonn, Germany; Nawroth, Frank; Hamburg, Germany; Pribbernow, Katrin; Magdeburg, Germany; Rösing, Benjamin, Bonn, Germany; Sehouli, Jalid; Berlin, Germany; Wallwiener, Diethelm; Tübingen, Germany; Weber, Wolfgang; Leipzig, Germany.

\section{Conflict of interest None.}

Open Access This article is distributed under the terms of the Creative Commons Attribution Noncommercial License which permits any noncommercial use, distribution, and reproduction in any medium, provided the original author(s) and source are credited.

\section{References}

1. Lee SJ, Schover LR, Partridge AH, Patrizio P, Wallace WH, Hagerty K, Beck LN, Brennan LV, Oktay K, American Society of Clinical Oncology (2006) American Society of Clinical Oncology recommendations on fertility preservation in cancer patients. J Clin Oncol 24:2917-2931

2. Jeruss JS, Woodruff TK (2009) Preservation of fertility in patients with cancer. N Engl J Med 360:902-911

3. FertiPROTEKT. Website of the "Network for fertility preservation before chemo and radiotherapy", http://www.fertiprotekt.eu. Responsible: Prof. Dr. Michael von Wolff. Installed 01' 2007, Last update 03' 2009

4. Al-Inany HG, Abou-Setta AM, Aboulghar M (2007) Gonadotrophin-releasing hormone antagonists for assisted conception: a Cochrane review. Reprod Biomed Online 14:640-649

5. von Wolff M, Thaler CJ, Frambach T, Zeeb C, Lawrenz B, Popovici RM, Strowitzki T (2009) Ovarian stimulation to cryopreserve fertilized oocytes in cancer patients can be started in the luteal phase. Fertil Steril 92:1360-1365

6. Bodri D, Guillén JJ, Galindo A, Mataró D, Pujol A, Coll O (2009) Triggering with human chorionic gonadotropin or a gonadotropin-releasing hormone agonist in gonadotropin-releasing hormone antagonist-treated oocyte donor cycles: findings of a large retrospective cohort study. Fertil Steril 91:365-371

7. Oktay K, Hourvitz A, Sahin G, Oktem O, Safro B, Cil A, Bang H (2006) Letrozole reduces estrogen and gonadotropin exposure in women with breast cancer undergoing ovarian stimulation before chemotherapy. J Clin Endocrinol Metab 91:3885-3890

8. Barritt J, Luna M, Duke M, Grunfeld L, Mukheerje T, Sandler B, Copperman AB (2007) Report of four donor-recipient oocyte Cryopreservation cycles resulting in high pregnancy and implantation rates. Fertil Steril 87:189e13-189e17

9. Cobo A, Bellver J, Domingo J, Pérez S, Crespo J, Pellicer A, Remohi J (2008) New options in assisted reproduction technology: the Cryotop method of oocyte vitrification. RBM Online 17:68-72

10. Lawrenz B, Jauckus J, Kupka M, Strowitzki T, von Wolff M (2010) Efficacy and safety of ovarian stimulation before chemotherapy in 205 cases. Fertil Steril (Epub ahead of print)

11. Lawrenz B, Jauckus J, Kupka M, Strowitzki T, von Wolff M (2011) Fertility preservation in $>1000$ patients-patients characteristics, spectrum, efficacy and risks of applied preservation techniques. Arch Gynecol Obstet (in press)
12. Montag M, Tolba R, Schulz M, Sadek F, van der Ven H (2007) Untersuchungen zum Einfluss des Mediums auf den Transport von Ovarialgewebe im Rahmen der Fertilitätsprotektion. J Reprod Endokrinol 5:264

13. Andersen CY, Rosendahl M, Byskov AG, Loft A, Ottosen C, Dueholm M, Schmidt KL, Andersen AN, Ernst E (2008) Two successful pregnancies following autotransplantation of frozen/ thawed ovarian tissue. Hum Reprod 23:2266-2272

14. Isachenko V, Isachenko E, Weiss JM, Todorov P, Kreienberg R (2009) Cryobanking of human ovarian tissue for anti-cancer treatment: comparison of vitrification and conventional freezing. Cryo Lett 30:449-454

15. von Wolff M, Donnez J, Hovatta O, Keros V, Maltaris T, Montag M, Salle B, Sonmezer M, Andersen CY (2009) Cryopreservation and autotransplantation of human ovarian tissue prior to cytotoxic therapy - a technique in its infancy but already successful in fertility preservation. Eur J Cancer 45:1547-1553

16. Schmidt KT, Rosendahl M, Ernst E, Loft A, Andersen AN, Dueholm M, Ottosen C, Andersen CY (2010) Autotransplantation of cryopreserved ovarian tissue in 12 women with chemotherapyinduced premature ovarian failure: the Danish experience. Fertil Steril (Epub ahead of print)

17. Bittinger SE, Nazaretian SP, Gook DA, Parmar C, Harrup RA, Stern CJ (2010) Detection of Hodgkin lymphoma within ovarian tissue. Fertil Steril (Epub ahead of print)

18. Sánchez-Serrano M, Novella-Maestre E, Roselló-Sastre E, Camarasa N, Teruel J, Pellicer A (2009) Malignant cells are not found in ovarian cortex from breast cancer patients undergoing ovarian cortex cryopreservation. Hum Reprod 24:2238-2243

19. Meirow D, Hardan I, Dor J, Fridman E, Elizur S, Ra'anani H, Slyusarevsky E, Amariglio N, Schiff E, Rechavi G, Nagler A, Ben Yehuda D (2008) Searching for evidence of disease and malignant cell contamination in ovarian tissue stored from hematologic cancer patients. Hum Reprod 23:1007-1013

20. Blumenfeld Z, von Wolff M (2008) GnRH-analogues and oral contraceptives for fertility preservation in women during chemotherapy. Hum Reprod Update 14:543-552

21. von Wolff M, Kämmerer U, Kollmann Z, Santi A, Dietl J, Frambach T (2010) Combination of gonadotropin-releasing hormone $(\mathrm{GnRH})$ agonists with GnRH antagonists before chemotherapy reduce but do not completely prevent a folliclestimulating hormone flare-up. Fertil Steril (in press)

22. Beck-Fruchter R, Weiss A, Shalev E (2008) GnRH agonist therapy as ovarian protectants in female patients undergoing chemotherapy: a review of the clinical data. Hum Reprod Update 14:553-561

23. Clowse ME, Behera MA, Anders CK, Copland S, Coffman CJ, Leppert PC, Bastian LA (2009) Ovarian preservation by GnRH agonists during chemotherapy: a meta-analysis. J Womens Health (Larchmt) 18(3):311-319

24. Ben-Aharon I, Gafter-Gvili A, Leibovici L, Stemmer SM (2010) Pharmacological interventions for fertility preservation during chemotherapy: a systematic review and meta-analysis. Breast Cancer Res Treat 122:803-811

25. Bedaiwy MA, Abou-Setta AM, Desai N, Hurd W, Starks D, ElNashar SA, Al-Inany HG, Falcone T (2010) Gonadotropinreleasing hormone analog cotreatment for preservation of ovarian function during gonadotoxic chemotherapy: a systematic review and meta-analysis. Fertil Steril 95:906-914

26. Olive DL (2008) Gonadotropin-releasing hormone agonists for endometriosis. N Engl J Med 359:1136-1142

27. Huober-Zeeb C, Lawrenz B, Popovici RM, Strowitzki T, Germeyer A, Stute P, von Wolff M (2010) Improving fertility preservation in cancer: ovarian tissue cryobanking followed by ovarian stimulation can be efficiently and safely combined. Fertil Steril (Epub ahead of print) 
28. Maman E, Prokopis K, Levron J, Carmely A, Dor J, Meirow D (2009) Does controlled ovarian stimulation prior to chemotherapy increase primordial follicle loss and diminish ovarian reserve? An animal study. Hum Reprod 24:206-210

29. Wallace WH, Thomson AB, Kelsey TW (2003) The radiosensitivity of the human oocyte. Hum Reprod 18:117-121

30. Wo JY, Viswanathan AN (2009) Impact of radiotherapy on fertility, pregnancy, and neonatal outcomes in female cancer patients. Int J Radiat Oncol Biol Phys 73:1304-1312

31. Bisharah M, Tulandi $T$ (2003) Laparoscopic preservation of ovarian function: an underused procedure. Am J Obstet Gynecol 188:367-370

32. Bloemers MC, Portelance L, Legler C, Renaud MC, Tan SL (2010) Preservation of ovarian function by ovarian transposition prior to concurrent chemotherapy and pelvic radiation for cervical cancer. A case report and review of the literature. Eur $\mathbf{J}$ Gynaecol Oncol 31:194-197

33. Anderson B, LaPolla J, Turner D, Chapman G, Buller R (1993) Ovarian transposition in cervical cancer. Gynecol Oncol 49:206-214

34. Sankila R, Heinävaara S, Hakulinen T (1994) Survival of breast cancer patients after subsequent term pregnancy: "healthy mother effect". Am J Obstet Gynecol 170:818-823

35. Azim AA, Costantini-Ferrando M, Oktay K (2008) Safety of fertility preservation by ovarian stimulation with letrozole and gonadotropins in patients with breast cancer: a prospective controlled study. J Clin Oncol 26:2630-2635

36. German Hodgkin study group. GHSG Studienzentrale Uniklinik Cologne Kerpener Str. 6250924 Cologne, Germany. http://www.ghsg.org/

37. Denschlag D, von Wolff M, Amant F, Kesic V, Reed N, Schneider A, Rodolakis A (2010) Fertility preservation in borderline ovarian neoplasm (tumor of low malignant potential): ovarian stimulation and oocyte retrieval after conservative surgery. Gynecol Obstet Invest 70:160-165

38. Fain-Kahn V, Poirot C, Uzan C, Prades M, Gouy S, Genestie C, Duvillard P, Morice P (2009) Feasibility of ovarian cryopreservation in borderline ovarian tumours. Hum Reprod 24:850-855

39. Walshe JM, Denduluri N, Swain S (2006) Amenorrhea in premenopausal women after adjuvant chemotherapy for breast cancer. J Clin Oncol 24:5769-5779

40. Behringer K, Breuer K, Reineke T, May M, Nogova L, Klimm B, Schmitz T, Wildt L, Diehl V, Engert A, German Hodgkin's Lymphoma Study Group (2005) Secondary amenorrhea after Hodgkin's lymphoma is influenced by age at treatment, stage of disease, chemotherapy regimen, and the use of oral contraceptives during therapy: a report from the German Hodgkin's Lymphoma Study Group. J Clin Oncol 23:7555-7564 